\title{
Preparasi Salbutamol Sulfat dalam Pembawa Vesikuler Etosom
}

\section{Nur illiyyin Akib*,1, Ines Septiani', Wa Ode Sitti Zubaydah', Halimahtussaddiyah ${ }^{2}$, Rifa'atul Mahmudah $^{1}$}

\author{
${ }^{1}$ Fakultas Farmasi, Universitas Halu Oleo, Kendari, Indonesia \\ 2Program Studi Kimia, Fakultas Matematikan dan IImu Pengetahuan Alam, Universitas Halu Oleo, \\ Kendari, Indonesia \\ ${ }^{\star}$ E-mail: nurilliyyin@ymail.com
}

(Submit 15/10/2020, Revisi 26/11/2020, Diterima 19/12/2020, Terbit 25/4/2021)

\begin{abstract}
Abstrak
Salbutamol sulfat merupakan bronkodilator pilihan pertama pada penanganan asma. Pemberian oral salbutamol sulfat memiliki waktu paruh yang relatif pendek dan bioavailabilitas $50 \%$ sebagai akibat dari metabolisme di hati dan degradasi pada dinding usus. Rute selain inhalasi yang dapat dipertimbangkan adalah transdermal. Etosom merupakan salah satu bentuk sistem penghantaran transdermal dengan kemampuan penetrasi yang lebih baik dibandingkan sistem vesikuler lainnya. Penelitian ini bertujuan memperoleh formula dan metode preparasi yang sesuai untuk preparasi salbutamol sulfat ke dalam pembawa vesikuler etosom. Preparasi dilakukan dengan metode panas $\left(40^{\circ} \mathrm{C}\right)$ dan metode dingin $\left(30^{\circ} \mathrm{C}\right)$ dengan variasi konsentrasi fosfatidilkolin sebagai pembentuk vesikel (2\% dan $3 \%$ ) dan etanol sebagai peningkat penetrasi ke dalam kulit $(20 \%, 30 \%$, dan $40 \%)$. Karakteristik vesikel yang dianalisis adalah ukuran, bentuk, dan efisiensi penjerapan vesikel. Ukuran dan bentuk vesikel diamati dengan mikroskop optik binokuler. Analisis efisiensi penjerapan dilakukan dengan metode spektrofotometri pada panjang gelombang $275.6 \mathrm{~nm}$. Vesikel yang dihasilkan dari kedua metode berupa Small Unilamellar Vesicle (SUV) dengan ukuran vesikel pada metode panas adalah 31,3-48,8 $\mathrm{nm}$ dan metode dingin adalah $25,4-44,9 \mathrm{~nm}$. Nilai efisiensi penjerapan salbutamol sulfat dalam vesikel etosom yang dipreparasi dengan metode panas yaitu $42,66 \%$ dan pada metode dingin yaitu $53,83 \%$. Disimpulkan bahwa metode dingin lebih sesuai digunakan untuk preparasi salbutamol sulfat dalam pembawa vesikular etosom dengan konsentrasi fosfatidilkolin $2 \%$ dan etanol $40 \%$.
\end{abstract}

Kata kunci: Etosom, Metode panas dan dingin, Salbutamol Sulfat.

\section{Pendahuluan}

Salbutamol sulfat merupakan golongan agonis $\beta_{2}$ adrenergik dan bekerja sebagai bronkodilator paling efektif sebagai pilihan pertama penanganan serangan asma ${ }^{1}$. Pemberian oral salbutamol sulfat memiliki waktu paruh yang relatif pendek dan bioavailabilitas $50 \%$ sebagai akibat dari metabolisme di hati dan degradasi pada dinding usus $^{2}$. Rute selain inhalasi yang dapat dipertimbangkan dalam pemberian salbutamol sulfat adalah transdermal. 
Masalah utama pada rute transdermal yaitu sulitnya menembus lapisan kulit, terutama bagi zat aktif hidrofilik termasuk salbutamol sulfat. Maka dipreparasi sistem penghantar obat transdermal berupa vesikel. Salah satu vesikel yang umum digunakan adalah etosom ${ }^{3}$. Kandungan etanol yang tinggi dalam etosom mampu merusak struktur stratum corneum yang tersusun atas sel-sel hidrofobik berupa keratin ${ }^{4,5}$. Elastisitas etosom karena adanya kandungan etanol dan fosfolipid diduga sebagai faktor utama yang meningkatkan kemampuan obat untuk berpenetrasi lebih dalam ke kulit6,7. Etosom terbukti memiliki kemampuan yang lebih baik dalam melokalisasi zat aktif di target yang dituju $^{8}$, penetrasi yang lebih baik dibandingkan sistem vesikuler lainnya ${ }^{9}$, serta lebih unggul dalam pelepasan obat dan bioavailabilitas dibandingkan liposom ${ }^{10}$.

Lebih lanjut, Chang dkk dalam penelitiannya memperoleh bahwa silymarin dalam vesikel etosom terakumulasi tinggi di paru-paru sehingga etosom memiliki potensi untuk digunakan untuk menghantarkan obat dengan target kerja di paru-paru ${ }^{11}$.

Salah satu parameter kualitas etosom adalah nilai efisiensi penjerapannya (\%EE). Nilai ini dipengaruhi oleh konsentrasi eksipien dan metode preparasi. Maestrelli dkk memperoleh adanya perbedaan nilai \%EE berdasarkan metode preparasi yang digunakan ${ }^{12}$. Salah satu metode dasar yang sederhana dan mudah dalam preparasi etosom tanpa melibatkan peralatan canggih adalah metode panas dan dingin. Perbedaan utama dari kedua metode tersebut adalah suhu yang digunakan ${ }^{13}$.

\section{Metode}

Alat

Alat yang digunakan dalam penelitian ini meliputi gelas kimia $\left(\right.$ Pyrex $\left.^{\circledR}\right)$, gelas ukur $\left(\right.$ Pyrex $\left.^{\circledR}\right)$, hot plate $\left(\right.$ Stuart $\left.^{\circledR}\right)$, kaca objek $\left(\right.$ Kudos $\left.^{\circledR}\right)$, karet penghisap $\left(\mathrm{D}^{\circ} \mathrm{N}^{\circledR}\right)$, labu takar $\left(\right.$ Pyrex $^{\circledR}$ ), mikroskop optik (Leica ${ }^{\circledR}$ ), pengaduk magnetik (Stuart ${ }^{\circledR}$ ), pipet ukur (Pyrex ${ }^{\circledR}$ ), sentrifugator (Boeco S- $8^{\circledR}$ ), spektrofotometer UV-Vis (Jenway 6800 ${ }^{\circledR}$ ), sonikator $\left(\right.$ Kudos $^{\circledR}$ ), timbangan analitik (Precisa XB 220A ${ }^{\circledR}$ ), termometer, pipet tetes, batang pengaduk, kuvet, sendok tanduk, tabung sentrifugator, rak tabung, statif, dan klem.

\section{Bahan}

Bahan yang digunakan dalam penelitian ini meliputi air suling (Otsuka $\left.{ }^{\circledR}\right)$, fosfatidilkolin (Sigma Aldrich ${ }^{\circledR}$ ), salbutamol sulfat (hibah dari PT. Dexa Medica), etanol (Merck, dikemas oleh PT. Brataco), dan propilen glikol (DOW).

\section{Formula suspensi salbutamol-etosom}

Suspensi salbutamol sulfat-etosom dibuat dalam volume $50 \mathrm{~mL}$ dengan kadar salbutamol sulfat $0,1 \%$. Formula suspensi Salbutamol-Etosom dapat dilihat pada tabel 1. 
Tabel 1. Formula Suspensi Salbutamol-Etosom

\begin{tabular}{cccccc}
\hline Formula & $\begin{array}{c}\text { Fosfatidilkolin } \\
(\% \mathbf{w} / \mathbf{v})\end{array}$ & $\begin{array}{c}\text { Etanol } \\
(\% \mathbf{v} / \mathbf{v})\end{array}$ & $\begin{array}{c}\text { Propilen } \\
\text { glikol } \\
(\% \mathbf{\%} / \mathbf{v})\end{array}$ & $\begin{array}{c}\text { Air suling } \\
(\% \mathbf{\%} / \mathbf{v})\end{array}$ & $\begin{array}{c}\text { Salbutamol } \\
\text { sulfat }(\% \mathbf{\%} / \mathbf{v})\end{array}$ \\
\hline A & 2 & 20 & 1 & 76,9 & 0,1 \\
B & 2 & 30 & 1 & 66,9 & 0,1 \\
C & 2 & 40 & 1 & 56,9 & 0,1 \\
D & 3 & 20 & 1 & 75,9 & 0,1 \\
E & 3 & 30 & 1 & 65,9 & 0,1 \\
F & 3 & 40 & 1 & 55,9 & 0,1 \\
\hline
\end{tabular}

Prosedur pembuatan

\section{A. Metode panas}

Fosfatidilkolin dicampurkan ke dalam air suling $\left(40^{\circ} \mathrm{C}\right)$ menghasilkan campuran A. Etanol $96 \%$ dan propilen glikol dicampur dalam wadah yang berbeda menghasilkan campuran B, lalu dimasukkan ke dalam campuran A dan diaduk (700 rpm, 5 menit) membentuk campuran C Salbutamol sulfat dilarutkan dalam air suling dan ditambahkan pada campuran (C). Air suling ditambahkan sedikit demi sedikit dan diaduk (5 menit). Suspensi didinginkan pada suhu ruang, disimpan dalam lemari pendingin, dan disonikasi (15 menit) ${ }^{14,15}$.

\section{B. Metode dingin}

Fosfatidilkolin dicampurkan ke dalam air suling $\left(30^{\circ} \mathrm{C}\right)$ menghasilkan campuran A. Salbutamol sulfat dilarutkan dalam air suling lalu dimasukkan pada campuran A dan diaduk (700 rpm 5 menit) menghasilkan campuran B. Propilen glikol dan etanol 96\% dicampurkan dalam wadah terpisah menghasilkan campuran $\mathrm{C}$ lalu dimasukkan ke dalam campuran B. Air suling ditambahkan sedikit demi sedikit dan diaduk (5 menit). Suspensi didinginkan pada suhu ruang, disimpan dalam lemari pendingin, dan disonikasi (15 menit) ${ }^{14,15}$.

\section{Pengamatan Morfologi dan Ukuran Vesikel}

Satu tetes suspensi etosom salbutamol sulfat diletakkan pada permukaan kaca objek. Bentuk dan ukuran vesikel diamati menggunakan mikroskop optik dengan perbesaran 1000 kali $^{15,16}$.

\section{Pengukuran Efisiensi Penjerapan (\%EE)}

Suspensi disentrifugasi (6.000 rpm, 2 jam). Supernatan diambil $1 \mathrm{~mL}$ dan diencerkan dengan air suling hingga $100 \mathrm{~mL}$, kemudian diukur serapannya pada panjang gelombang maksimum $275,6 \mathrm{~nm}^{16,17}$. 


\section{Hasil}

Hasil analisis bentuk vesikel menunjukkan bahwa formula yang dibuat dengan metode panas dan metode dingin menghasilkan vesikel kecil lapis tunggal (Small Unilamelar Vesicle/SUV). Hasil pengamatan disajikan pada Gambar 1.
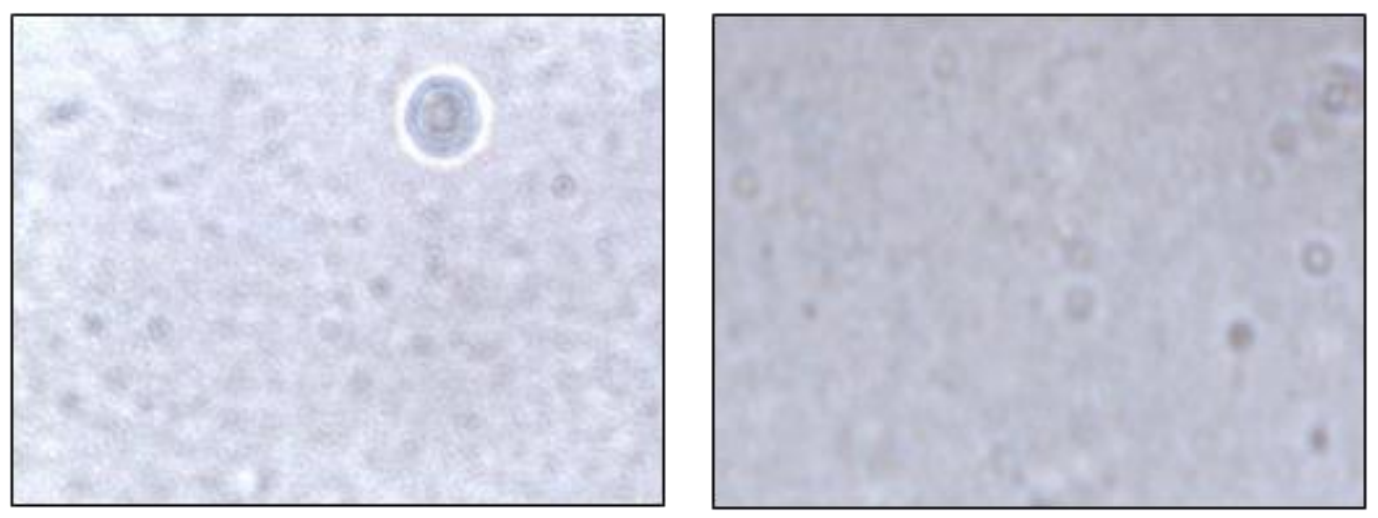

Gambar 1. Vesikel yang Teramati pada Perbesaran 1000x: (a) Metode panas (b) Metode dingin

Vesikel yang diperoleh dari metode panas memiliki ukuran maksimum 48,8 nm dan minimum $31,3 \mathrm{~nm}$, spapangkan ukuran vesikel terbesar(\$)engan metode dingin maksimum $44,9 \mathrm{~nm}$ dan minimum $25,4 \mathrm{~nm}$. Hal ini sesuai untuk penghantaran topikal dan transdermal yaitu 25-100 nm. Hasil pengukuran disajikan pada Tabel 2 dan Tabel 3.

Tabel 2. Ukuran vesikel formula dengan metode panas pada perbesaran 1000x

\begin{tabular}{ccccccc}
\hline \multirow{2}{*}{ Nilai } & \multicolumn{6}{c}{ Formula } \\
\cline { 2 - 7 } & A & B & C & $D$ & $E$ & $F$ \\
\hline R1 & $46,9 \mathrm{~nm}$ & $41,0 \mathrm{~nm}$ & $41,0 \mathrm{~nm}$ & $43,0 \mathrm{~nm}$ & $41,1 \mathrm{~nm}$ & $39,1 \mathrm{~nm}$ \\
R2 & $41,0 \mathrm{~nm}$ & $43,0 \mathrm{~nm}$ & $39,1 \mathrm{~nm}$ & $48,8 \mathrm{~nm}$ & $41,0 \mathrm{~nm}$ & $35,2 \mathrm{~nm}$ \\
R3 & $44,9 \mathrm{~nm}$ & $41,0 \mathrm{~nm}$ & $44,9 \mathrm{~nm}$ & $31,3 \mathrm{~nm}$ & $37,1 \mathrm{~nm}$ & $31,3 \mathrm{~nm}$ \\
R4 & $46,9 \mathrm{~nm}$ & $44,9 \mathrm{~nm}$ & $43,0 \mathrm{~nm}$ & $31,3 \mathrm{~nm}$ & $37,1 \mathrm{~nm}$ & $31,3 \mathrm{~nm}$ \\
R5 & $44,9 \mathrm{~nm}$ & $41,0 \mathrm{~nm}$ & $45,0 \mathrm{~nm}$ & $41,0 \mathrm{~nm}$ & $37,1 \mathrm{~nm}$ & $31,3 \mathrm{~nm}$ \\
Maksimal & $46,9 \mathrm{~nm}$ & $44,9 \mathrm{~nm}$ & $45,0 \mathrm{~nm}$ & $48,8 \mathrm{~nm}$ & $41,1 \mathrm{~nm}$ & $39,1 \mathrm{~nm}$ \\
Minimal & $41,0 \mathrm{~nm}$ & $41,0 \mathrm{~nm}$ & $39,1 \mathrm{~nm}$ & $31,3 \mathrm{~nm}$ & $37,1 \mathrm{~nm}$ & $31,3 \mathrm{~nm}$ \\
Rata-rata & $44,9 \mathrm{~nm}$ & $42,1 \mathrm{~nm}$ & $42,6 \mathrm{~nm}$ & $39,0 \mathrm{~nm}$ & $38,6 \mathrm{~nm}$ & $33,6 \mathrm{~nm}$ \\
\hline
\end{tabular}


Tabel 3. Ukuran vesikel formula dengan metode dingin pada perbesaran 1000x

\begin{tabular}{ccccccc}
\hline \multirow{2}{*}{ Nilai } & \multicolumn{6}{c}{ Formula } \\
\cline { 2 - 7 } & A & B & C & D & E & F \\
\hline R1 & $39,1 \mathrm{~nm}$ & $33,2 \mathrm{~nm}$ & $33,2 \mathrm{~nm}$ & $43,0 \mathrm{~nm}$ & $39,1 \mathrm{~nm}$ & $25,4 \mathrm{~nm}$ \\
R2 & $41,1 \mathrm{~nm}$ & $31,3 \mathrm{~nm}$ & $32,2 \mathrm{~nm}$ & $33,2 \mathrm{~nm}$ & $33,2 \mathrm{~nm}$ & $27,3 \mathrm{~nm}$ \\
R3 & $43,0 \mathrm{~nm}$ & $35,2 \mathrm{~nm}$ & $40,0 \mathrm{~nm}$ & $35,2 \mathrm{~nm}$ & $39,1 \mathrm{~nm}$ & $31,3 \mathrm{~nm}$ \\
R4 & $37,1 \mathrm{~nm}$ & $44,9 \mathrm{~nm}$ & $34,2 \mathrm{~nm}$ & $41,0 \mathrm{~nm}$ & $31,3 \mathrm{~nm}$ & $29,3 \mathrm{~nm}$ \\
R5 & $44,9 \mathrm{~nm}$ & $43,0 \mathrm{~nm}$ & $41,0 \mathrm{~nm}$ & $31,3 \mathrm{~nm}$ & $33,2 \mathrm{~nm}$ & $27,3 \mathrm{~nm}$ \\
Maksimal & $44,9 \mathrm{~nm}$ & $44,9 \mathrm{~nm}$ & $41,0 \mathrm{~nm}$ & $43,0 \mathrm{~nm}$ & $39,1 \mathrm{~nm}$ & $31,3 \mathrm{~nm}$ \\
Minimal & $37,1 \mathrm{~nm}$ & $31,3 \mathrm{~nm}$ & $32,2 \mathrm{~nm}$ & $31,3 \mathrm{~nm}$ & $31,3 \mathrm{~nm}$ & $25,4 \mathrm{~nm}$ \\
Rata-rata & $41,0 \mathrm{~nm}$ & $37,5 \mathrm{~nm}$ & $36,1 \mathrm{~nm}$ & $36,7 \mathrm{~nm}$ & $35,1 \mathrm{~nm}$ & $28,1 \mathrm{~nm}$ \\
\hline
\end{tabular}

Nilai pengukuran efisiensi penjerapan (\%EE) dengan metode metode panas diperoleh maksimum pada formula $C(42,66 \%)$ dan minimum pada formula $D(23,98 \%)$. Nilai $\%$ EE dengan metode dingin diperoleh maksimum pada formula $C(53,83 \%)$ dan minimum pada formula D (24,77\%). Hasil \%EEdisajikan pada Tabel 4 dan Tabel 5.

Tabel 4. Nilai \%EE formula etosom yang dipreprasi dengan metode panas

\begin{tabular}{cccccccc}
\hline Formula & $\begin{array}{c}\text { Fosfatidil- } \\
\text { kolin } \\
(\% \mathbf{w} / \mathbf{v})\end{array}$ & $\begin{array}{c}\text { Etanol } \\
(\% \mathbf{\%} / \mathbf{v})\end{array}$ & Absorbansi & $\begin{array}{c}\text { Qs } \\
(\mathbf{m g})\end{array}$ & $\begin{array}{c}\text { Qt } \\
(\mathbf{m g})\end{array}$ & $\begin{array}{c}\text { Qt-Qs } \\
(\mathbf{m g})\end{array}$ & \%EE \\
\hline A & 2 & 20 & 0,3934 & 36,3585 & 50 & 13,6415 & 27,28 \\
B & 2 & 30 & 0,3575 & 32,9717 & 50 & 17,0283 & 34,05 \\
C & 2 & 40 & 0,3119 & 28,6698 & 50 & 21,3302 & 42,66 \\
D & 3 & 20 & 0,4109 & 38,0094 & 50 & 11,9906 & 23,98 \\
E & 3 & 30 & 0,3969 & 36,6887 & 50 & 13,3113 & 26,62 \\
F & 3 & 40 & 0,3760 & 34,7170 & 50 & 15,2830 & 30,56 \\
\hline
\end{tabular}

Tabel 5. Nilai \%EE formula etosom yang dipreparasi dengan metode dingin

\begin{tabular}{cccccccc}
\hline Formula & $\begin{array}{c}\text { Fosfatidil- } \\
\text { kolin } \\
(\% \mathbf{w} / \mathbf{v})\end{array}$ & $\begin{array}{c}\text { Etanol } \\
(\% \mathbf{\%} / \mathbf{v})\end{array}$ & Absorbansi & $\begin{array}{c}\mathbf{Q s} \\
(\mathbf{m g})\end{array}$ & $\begin{array}{c}\text { Qt } \\
(\mathbf{m g})\end{array}$ & $\begin{array}{c}\text { Qt-Qs } \\
(\mathbf{m g})\end{array}$ & \%EE \\
\hline A & 2 & 20 & 0,3436 & 31,6604 & 50 & 18,3396 & 36,67 \\
B & 2 & 30 & 0,3374 & 31,0755 & 50 & 18,9245 & 37,84 \\
C & 2 & 40 & 0,2527 & 23,0849 & 50 & 26,9151 & 53,83 \\
D & 3 & 20 & 0,4067 & 37,6132 & 50 & 12,3868 & 24,77 \\
E & 3 & 30 & 0,3590 & 33,1132 & 50 & 16,8868 & 33,77 \\
F & 3 & 40 & 0,2614 & 23,9057 & 50 & 26,0943 & 52,18 \\
\hline
\end{tabular}

Keterangan: Qt = jumlah salbutamol sulfat mula-mula

Qs $\quad=$ jumlah salbutamol sulfat yang tidak terjerap

Qt-Qs = jumlah salbutamol sulfat yang terjerap 


\section{Pembahasan}

Vesikel yang terbentuk dari kedua metode preparasi yang digunakan berupa vesikel kecil lapis tunggal (Small Unilamellar Vesicle/SUV). Tidak ada aturan jelas mengenai metode preparasi etosom dengan bentuk vesikel tertentu, umumnya semua metode pembuatan etosom akan menghasilkan vesikel dengan ukuran dan bentuk yang beragam ${ }^{18}$.

Diameter vesikel yang terbentuk baik metode panas dan dingin adalah 25-100 nm dimana ukuran ini dianggap sesuai untuk rute topikal dan transdermal yaitu $<200 \mathrm{~nm}^{19-}$ 21. Ukuran vesikel kemungkinan besar dipengaruhi oleh sonikasi yang merupakan salah satu metode untuk memperkecil ukuran vesikel. Selain itu sonikasi juga mampu meningkatkan nilai efisiensi penjerapan sampai pada titik tertentu22. Manfaat lain sonikasi adalah mengurangi terjadinya agregasi vesikel sehingga dapat dengan mudah diamati pada mikroskop ${ }^{23}$.

Terdapat perbedaan nilai \%EE yang dihasilkan dari kedua metode yang digunakan. Nilai \%EE maksimum pada metode dingin lebih besar dibandingkan dengan \%EE maksimum yang dihasilkan oleh metode panas. Sebelumnya Akib dkk mengatakan bahwa efisiensi penjerapan obat dalam vesikel etosom dapat dipengaruhi oleh metode preparasi ${ }^{24}$. Hasil penelitian ini serupa dengan hasil yang diperoleh Regunta dan Abbaraju yaitu nilai \%EE asam mefenamat dalam vesikel etosom lebih tinggi pada metode dingin $(94,4 \%)$ dibandingkan pada metode panas $(72,85 \%)$. Perbedaan nilai \%EE juga diperoleh Maestrelli dkk dalam penelitian serupa menggunakan zat aktif benzokain di mana metode Thin layer evaporation dan Reverse phase- evaporation menghasilkan \%EE yang lebih tinggi dibandingkan metode Freezing and Thawing dan Extrusion and sonication ${ }^{12}$.

Sifat hidrofilik dari salbutamol sulfat nampaknya juga memberikan pengaruh terhadap $\%$ EE pada metode dingin. Metode dingin sering digunakan pada zat aktif yang bersifat hidrofilik karena mampu menjerap lebih banyak obat ke dalam komparteman hidrofilik vesikel yaitu fase air yang terdapat pada bagian inti dari vesikel ${ }^{25}$.

Konsentrasi fosfolipid juga turut mempengaruhi \%EE, konsentrasi fosfolipid yang semakin tinggi akan meningkatkan jumlah vesikel yang terbentuk sehingga kapasitas obat yang dapat terjerap menjadi lebih besar ${ }^{26}$. Namun terdapat konsentrasi tertentu dimana penambahan ataupun pengurangan fosfolipid akan menyebabkan menurunnya nilai \%EE27, hal ini diperoleh pada hasil penelitian yaitu formula dengan $2 \%$ fosfatidilkolin memiliki \%EE yang lebih tinggi dibandingkan formula dengan $3 \%$ fosfatidilkolin. 
Konsentrasi etanol diduga turut memberikan pengaruh terhadap \%EE. Etanol yang mampu mempengaruhi struktur vesikel sehingga menjadi kurang rapat sehingga obat lebih mudah masuk ke dalam lipid bilayer ${ }^{26}$. Hal ini sejalan dengan hasil yang diperoleh yaitu \%EE maksimum terdapat pada formula C (etanol 40\%) dan \%EE minimum terdapat pada formula D (etanol 20\%). Beberapa studi melaporkan bahwa konsentrasi optimal etanol dalam pengembangan sistem etosom yang stabil adalah sekitar 3040\% ${ }^{28-30}$. Perlu dicatat bahwa penggunaan etanol di atas $40 \%$ menyebabkan vesikel menjadi sangat permeabel sehingga dapat terjadi 'kebocoran' yang kemudian menurunkan nilai \%EE ${ }^{27}$.

Berdasarkan hasil yang diperoleh, formula optimum adalah formula $\mathrm{C}$ yang memiliki nilai \%EE terbesar dengan konsentrasi fosfatidilkolin sebesar $2 \%$ dan etanol $40 \%$ yang dipreparasi dengan metode dingin. Semakin besar nilai \%EE berarti semakin banyak zat aktif yang terjerap dalam vesikel. Maka semakin banyak pula zat aktif yang dapat dihantarkan menuju target yang kemudian berpengaruh terhadap bioavailabilitas zat aktif.

\section{Kesimpulan}

Preparasi dengan metode panas maupun metode dingin menghasilkan jenis vesikel kecil lapis tunggal (SUV) dengan ukuran diameter 25,4-48,8 $\mathrm{nm}$. Nilai \%EE salbutamol sulfat dalam vesikel etosom menunjukkan adanya perbedaan nilai \%EE yaitu pada metode dingin $(53,83 \%)$ lebih besar dibandingkan metode panas $(42,66 \%)$.

\section{Daftar Pustaka}

1. Sukandar, E. Y., Retnosari A., Joseph I. S., I Ketut A., A. Adji P. S., dan Kusnandar. ISO Farmakoterapi. Jakarta: PT. ISFI Penerbitan; 2009.

2. Dipiro, J. T., Marie A. C., Barbara G. W., Terry L. S., Patrick M. M., Jill M. K., dan John C.R. Pharmacotherapy Principles and Practice. New York: The Mc Graw Hill Companies; 2008.

3. Luthfia Azzahra dan Ida Musfiroh. Etosom Sebagai Penghantar Obat Herbal Hidrofilik. Majalah farmasetika. 2018: 3(4); 85-93.

4. Shaik, S., Shaheda Sultana Shaik, V.Vasu Naik, Madhuri K. Ethosomes-An Emerging Approach for Vesicular Delivery System. International Journal of Universal Pharmacy and Bio Sciences. 2013.

5. Angadi, J., Sai Sowjanya K, Nama Sreekanth, Karuna B, Chandu Babu Rao. Ethosomes: A Novel Drug Carrier for Transdermal Drug Delivery. International Journal of Innovative Drug Discovery. 2013: 3(1).

6. Romero EL, Morilla MJ. Highly deformable and highly fluid vesicles as potential drug delivery Systems: theoretical and practical considerations. Int $\mathrm{J}$ Nanomedicine. 2013: 8; 3171-3186.

7. Ravi B Patel, Tejas B Patel, Suhagia B.N, Mehul N Patel, Mayur Patel, Parth Patel. Ethosome: An Emerging Targeted Drug Delivery System A Review. International Journal of Innovative Pharmaceutical Sciences and Research. 2014: 2(4); 941-961. 
8. Caddeo C, Sales OD, Valenti D. Inhibition of skin inflammation in mice by diclofenac in vesicular carriers: liposomes, ethosomes and PEVs. Int J Pharm. 2013: 443; 12836.

9. Vijayan Venugopal, Raymond Goh, Tan Yee Ping, Tan Jia Jin. Formulation Development and Characterization of Tea Tree Oil Loaded Ethosomes. Indonesian J. Pharm. 2015: 27(1); 44-52.

10. Ahad A, Aqil M, Kohli K. Enhanced transdermal delivery of an anti-hypertensive agent via nanoethosomes: statistical optimization, characterization and pharmacokinetic assessment. Int J Pharm. 2013: 443; 26-38.

11. Chang LW, Hou ML, Tsai TH. Silymarin in liposomes and ethosomes: pharmacokinetics and tissue distribution in free-moving rats by high-performance liquid chromatography-tandem mass spectrometry. J. Agric Food Chem. 2014;62(48):11657-11665.

12. Maestrelli F, Capasso G, Gonzalez-Rodriguez ML, Rabasco AM, Ghelardini C, Mura P. Effect of preparation technique on the properties and in vivo efficacy of benzocaine-loaded ethosomes. J Liposome Res. 2009;19(4):253-260.

13. Vikas Pandey, Dilip Golhane dan Rajesh Shukla. Ethosomes: Versatile Vesicular Carriers for efficient Transdermal Delivery of Therapeutic Agents. Journal Drug Delivery. 2015: 22 (8); 988-1002.

14. Anitha, P., S. Ramkanth, K. Uma Sankari, M. Alagusundaram, K. Gnanapraksah, P. Devaki Devi, et al. Ethosomes - A Noninvasive Vesicular Carrier for Transdermal Drug Delivery. International Journal of Review in Life Sciences. 201: 1(1); $17-24$.

15. Regunta Supraja dan Abbaraju Krishna Sailaja. Formulation of Mefenamic Acid loaded Ethosomal Gel by Hot dan Cold Method. Nano Biomed. Eng. 2017: 9(1); 2735.

16. Nirved Uppadhyay, Vyash Lokesh, Mishra Ganesh Prasad, Joshi Hemant. Formulation and Evaluation of Ethosomes of Sebasniea grandiflora Linn. Seeds. Novel Science: International Journal of Pharmaceutical Science. 2012: 1(6).

17. Rahman, L., Isryany I., dan Elly W. Kapasitas Jerap Niosom Terhadap Ketoprofen dan Prediksi Penggunaan Transdermal. Majalah Farmasi Indonesia. 2011: 22(2); 85 $-91$.

18. Ibrahim M Abdulbaqi, Yusrida Darwis, Nurzalina Abdul Karim Khan, Reem Abou Assi, dan Arshad A Khan. Ethosomal nanocarriers: the impact of constituents and formulation techniques on ethosomal properties, in vivo studies, and clinical trials. Int J Nanomedicine. 2016; 11: 2279-2304.

19. Khtar N, Pathak K. Cavamax W7. Composite ethosomal gel of clotrimazole for improved topical delivery: development and comparison with ethosomal gel. AAPS PharmSciTech. 2012;13(1):344-355.

20. Verma P, Pathak K. Nanosized ethanolic vesicles loaded with econazole nitrate for the treatment of deep fungal infections through topical gel formulation. Nanomedicine. 2012;8(4):489-496.

21. Kumari S, Pathak K. Cavamax W7 composite psoralen ethosomal gel versus Cavamax W7 psoralen solid complex gel for topical delivery: a comparative evaluation. Int J Pharm Investig. 2013;3(4):171-182.

22. Chen JG, Jiang $Y$, Yang $Z$. Preparation of triptolide ethosomes. Afr $J$ Pharm Pharmacol. 2012;6(13):998-1004. 
23. Dua, J. S., Rana A. T., dan Bhandari A. K. Liposome Methode of Preparation and Application. International Journal of Pharmaceutical Study and Research. 2012: $1(2) ; 14-20$.

24. Akib, N. I., Latifah R. dan Marianti A. M. Uji Permeasi In Vitro Gel Etosom Vitamin C. Majalah Farmasi dan Farmakologi. 2012: 16(1); 1-6.

25. Ashis, R. Ethosomes: Novel Approach in Transdermal Drug Delivery System. Research Journal of Pharmaceutical Dosage Form and Techqnology. 2010: 2(1): 1 6.

26. Chourasia, M.K., Lifeng K. dan Sui Y.C. Nanosized Ethosomes Bearing Ketoprofen For Improved Transdermal Delivery. Results in Pharma Sciences. 2011:1; 60 - 67.

27. Akib, N. I., Suryani, Halimahtussaddiyah R., dan Niken P. Preparasi Fenilbutazon dalam Pembawa Vesikular Etosom dengan Berbagai Variasi Konsentrasi Fosfatidilkolin dan Etanol. Medula. 2014: 2(1); 112 - 118.

28. Limsuwan T, Amnuaikit T. Development of ethosomes containing mycophenolic acid. Proc Chem. 2012: 4; 328-35.

29. Chiu WC, Chang $\mathrm{CH}$, Yang YM. Ethanol effects on the gelatin behavior of $\alpha-$ tocopherol acetate-encapsulated ethosomes with water soluble polymers. Colloid Polym Sci. 2013: 291; 1341-52.

30.Zhao YZ, Lu CT, Zhang Y, Jian Xiao, Ya-ping Zhao, Ji-Lai Tian, et al. Selection of high efficient transdermal lipid vesicle for curcumin skin delivery. Int J Pharm. 2013: $454 ; 302-9$. 